\title{
Quantitative assessment of histological changes in chronic gastritis after eradication of Helicobacter pylori
}

\author{
A Di Napoli, R Petrino, $M$ Boero, D Bellis, L Chiandussi
}

\begin{abstract}
Aims: To evaluate the effect of 10 day triple treatment on $H$ pylori eradication and associated gastrisis.

Methods: Fifty patients with $H$ pylori positive non-ulcer dyspepsia were treated for 10 days with amoxicillin, tinidazole, and bismuth salts. Histological examination of the antral mucosa was performed before (T0), six weeks (T1), and six months (T2) after treatment. The new Sydney classification of gastritis was used, using a score from 0 to 3 to grade degree of inflammation, atrophy, activity (intraepithelial or lamina propria damage) and $H$ pylori.

Results: At T0 all patients had chronic active gastritis. Lymphoid follicules were present in 12 cases. At T1 33 patients were $H$ pylori negative: the score showed a decrease of activity (from 2.5 to 0.54 ). The result was confirmed at T2 (mean score $0 \cdot 22$ ). Inflammation decreased from 1.8 to 1.4 at T2. Only one case of follicular gastritis was observed. In $H$ pylori positive patients the scores did not show significant modifications.

Conclusions: Ten day triple treatment is effective in eradicating $H$ pylori in $69 \%$ of cases, causing a decrease of the total score for gastritis. Activity, defined by polymorph infiltration, was promptly reduced when $H$ pylori was eradicated. There was a trend to a reduction in inflammation, but atrophy was irreversible.
\end{abstract}

School of Internal Medicine, S. Vito Hospital, Turin, Italy

A Di Napoli

R Petrino

L Chiandussi

Department of

Clinical Oncology and

Biomecial Science,

Section of

Histopathology,

University of Turin

D Bellis

Gastroenterology

Service, G Bosco

Hospital, Turin

M Boero

Correspondence to:

Correspondence to:
Dr Angelo Di Napoli

Institute of Internal $S$. Vito,

Medicine, Ospedale S. Vito
Strada S. Vito 34, 10133

Torino, Italy

Accepted for publication

14 February 1992
The pathogenic role of Helicobacter pylori in chronic active gastritis is now well recognised and supported by many studies. ${ }^{1-3}$ Histological observations show that $H$ pylori can adhere to the luminal surface of glandular cells beneath the mucous layer. ${ }^{45}$ Recent studies have shown that $H$ pylori produces cytotoxins and enzymes which cause mucosal damage: loss of microvilli, cellular vacuolisation, destruction of intercellular junctions, erosion of the mucosal surface. ${ }^{67}$ These changes always coincide with lymphocytic and polymorphonuclear infiltration that is particularly concentrated in the pitisthmus region. $^{23}$

Treatment of $H$ pylori infection with combinations of different antimicrobial drugs can eradicate the bacteria, and consequently modify the histological picture. ${ }^{89}$

Recognition of the importance of $H$ pylori in producing gastric inflammatory lesions resulted in a review of the histological classification of gastritis: a new scheme was proposed during the 1990 Sydney World Congress of Gastroenterology, called, for short, the Sydney system. ${ }^{10}$

\section{Methods}

Fifty consecutive patients, 28 of whom were male (mean age 48 years), with $H$ pylori positive non-ulcer dyspepsia were treated for 10 days with colloidal bismuth subcitrate $120 \mathrm{mg}$ four times a day, tinidazole $500 \mathrm{mg}$ twice a day, and amoxicillin $1 \mathrm{~g}$ twice a day. Infection was confirmed by histological evaluation of four antral biopsy specimens taken during endoscopy, and by a positive urease test. The same evaluations were performed six weeks (T1) and six months (T2) after treatment.

Paraffin wax sections were stained with haematoxylin and eosin and Giemsa. All the slides were observed blind by a pathologist (DB) and graded for the presence of gastritis and $H$ pylori according to the criteria outlined in the Sydney system. ${ }^{10}$ The variables considered were as follows:

Inflammation: indicated by the presence of chronic inflammatory cells in the lamina propria-lymphocytes, plasma cells, macrophages and histiocytes. The different types of gastritis, previously classified as superficial, diffuse, follicular and atrophic, ${ }^{11}$ were no longer considered separately, but were included, instead, in the degree of inflammation. Furthermore, the presence of lymphoid follicules was considered to be an aspect of the immunological reaction to $H$ pylori. ${ }^{12} 13$

Atrophy: indicated gastric gland loss; this was considered independently from inflammation and graded separately.

Activity of gastritis: the grade of "acute injury" suggested by polymorph infiltration in the lamina propria or in intraepithelial sites.

These variables were graded as $0=$ absent, 1 $=$ mild, $2=$ moderate, $3=$ severe. $H$ pylori was graded according to density: $0=$ absent, $1=$ occasional micro-organisms, 2 = patchy, $3=$ layer of bacteria. Intestinal metaplasia, when present, was given a score of 1 . The sum of the scores, ranging from 0 to 12 , or 13 , if intestinal metaplasia was present, was made for each patient, thus giving a quantitative evaluation of gastritis.

Variations in the scores from $\mathrm{T} 0$ for gastritis and $H$ pylori eradication were analysed by Student's $t$ test for matched data, calculating the confidence interval (CI). Significance was assessed using the Freadman test for non- 


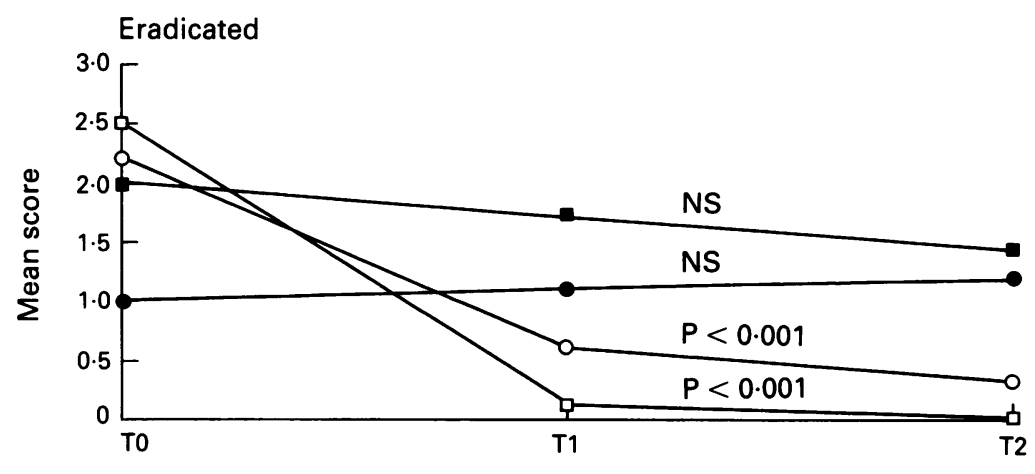

- Inflammation - Atrophy o Activity a Hpylori

Figure 1 Mean scores for gastritis in patients in whom $H$ pylori infection had been eradicated.

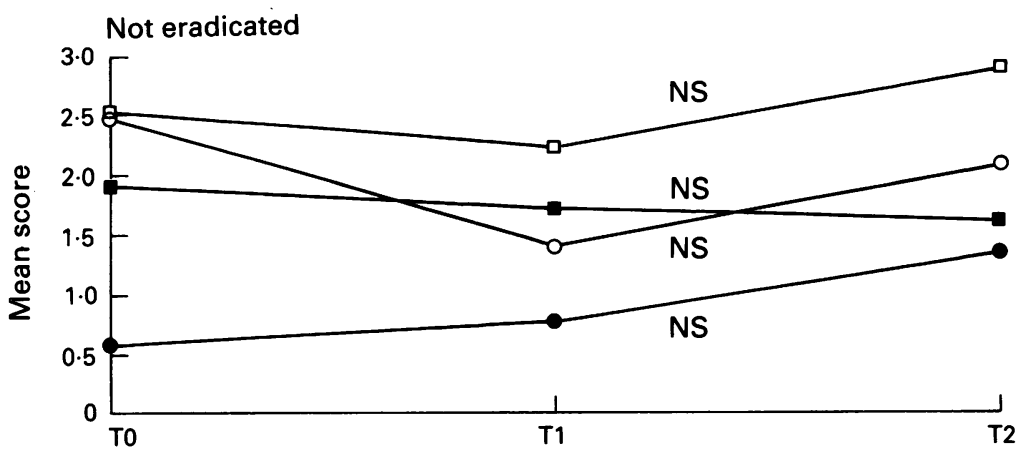

- Inflammation • Atrophy o Activity a Hpylori

Figure 2 Mean scores for gastritis in patients with continuing $H$ pylori infection. parametric data. The Spearman correlation coefficient was calculated to evaluate the possible relation between $H$ pylori positivity and histological damage.

\section{Results}

Before treatment all the patients infected with $H$ pylori had chronic active gastritis. Table 1 shows the prevalence of histological features in our series. The scores for single variables are illustrated in figs 1 and 2 . As regards inflammation, at T0 lymphoid follicules were found in 12 cases. The sum of the score is given in table 2.

All the patients completed the treatment, but two who refused a second endoscopy were excluded from further study. During treatment only four patients reported slight side effects, mainly vertigo, but this did not require them to stop or change treatment. Almost all patients reported relief of dyspeptic symptoms.

SIX WEEK RESULTS (T1)

At the second endoscopy 33 patients out of 48 $(69 \%)$ gave a negative result to the urea test and there was no histological evidence of $H$ pylori infection. For these patients the total score for gastritis showed a significant decrease (mean from 7.76 at T0 to 3.22 at T1; p $<0.01$, $95 \%$ CI 2.94 to 5.28 ), while in non-responders the score was only slightly reduced $(6 \cdot 31$ at $\mathrm{T} 2$; $\mathrm{p}>0.1, \mathrm{CI}-0.57$ to 3.32 ). A reduction in gastritis activity in those who were $H$ pylori positive was not significant $(2.33$ at $\mathrm{T} 0,1.46$ at $\mathrm{T} 1 ; \mathrm{CI} 0.08$ to $1.56 ; \mathrm{p}=0.04$ ), but was highly significant in $H$ pylori negative patients $(2 \cdot 13$ at

Table 1 Percentage distribution of gastric lesions at TO, T1, and T2

\begin{tabular}{|c|c|c|c|c|c|c|}
\hline & Score & $\begin{array}{l}\text { To } \\
(n=48)\end{array}$ & $\begin{array}{l}T 1- \\
(n=33)\end{array}$ & $\begin{array}{l}T 1+ \\
(n=15)\end{array}$ & $\begin{array}{l}T 2- \\
(n=18)\end{array}$ & $\begin{array}{l}T 2+ \\
(n=8)\end{array}$ \\
\hline Inflammation: & $\begin{array}{l}0 \\
1 \\
2 \\
3\end{array}$ & $\begin{array}{l}63 \%(11) \\
53 \%(30) \\
15 \%(7)\end{array}$ & $\begin{array}{l}10 \%(3) \\
10 \%(8) \\
67 \%(22)\end{array}$ & $\begin{array}{l}40 \%(6) \\
47 \%(7) \\
13 \%(2)\end{array}$ & $\begin{array}{l}22 \%(4) \\
17 \% \text { (3) } \\
61 \%(11)\end{array}$ & $\begin{array}{l}50 \%(4) \\
38 \%(3) \\
12 \%(1)\end{array}$ \\
\hline Atrophy: & $\begin{array}{l}0 \\
1 \\
2 \\
3\end{array}$ & $\begin{array}{l}50 \%(27) \\
12 \%(4) \\
27 \%(14) \\
12 \%(3)\end{array}$ & $\begin{array}{l}44 \%(14) \\
17 \%(8) \\
28 \%(9) \\
11 \%(2)\end{array}$ & $\begin{array}{l}53 \%(8) \\
20 \%(3) \\
13 \%(2) \\
13 \%(2)\end{array}$ & $\begin{array}{l}33 \%(6) \\
33 \%(6) \\
17 \%(3) \\
17 \%(3)\end{array}$ & $\begin{array}{l}38 \%(3) \\
12 \%(1) \\
25 \%(2) \\
25 \%(2)\end{array}$ \\
\hline Activity: & $\begin{array}{l}0 \\
1 \\
2 \\
3\end{array}$ & $\begin{array}{l}6 \%(3) \\
13 \%(5) \\
15 \%(13) \\
66 \%(27)\end{array}$ & $\begin{array}{c}61 \%(21) \\
28 \%(8) \\
6 \%(2) \\
6 \%(2)\end{array}$ & $\begin{array}{l}27 \%(4) \\
13 \%(2) \\
47 \%(7) \\
13 \%(2)\end{array}$ & $\begin{array}{c}83 \%(15) \\
11 \%(2) \\
6 \%(1)\end{array}$ & $\begin{array}{l}12 \%(1) \\
63 \%(5) \\
25 \%(2)\end{array}$ \\
\hline$H$ pylori infection: & $\begin{array}{l}0 \\
1 \\
2 \\
3\end{array}$ & $\begin{array}{c}8 \%(4) \\
36 \%(17) \\
56 \%(27)\end{array}$ & $100 \%(33)$ & $\begin{array}{l}20 \%(3) \\
60 \%(9) \\
20 \%(3)\end{array}$ & $100 \%(18)$ & $\begin{array}{l}38 \%(3) \\
38 \%(3) \\
25 \%(2)\end{array}$ \\
\hline Intestinal metaplasia: & $\begin{array}{l}0 \\
1\end{array}$ & $\begin{array}{l}82 \%(39) \\
18 \%(9)\end{array}$ & $\begin{array}{l}85 \%(28) \\
15 \%(5)\end{array}$ & $\begin{array}{l}73 \% \text { (11) } \\
27 \% \text { (4) }\end{array}$ & $\begin{array}{l}67 \%(12) \\
33 \%(6)\end{array}$ & $\begin{array}{l}88 \%(7) \\
12 \%(1)\end{array}$ \\
\hline
\end{tabular}

Table 2 Mean value of scores for variables studied and of total score for gastritis

\begin{tabular}{llllll}
\hline & $\begin{array}{l}T 0 \\
(n=48)\end{array}$ & $\begin{array}{l}T 1- \\
(n=33)\end{array}$ & $\begin{array}{l}T 1+ \\
(n=15)\end{array}$ & $\begin{array}{l}T 2- \\
(n=18)\end{array}$ & $\begin{array}{l}T 2+ \\
(n=8)\end{array}$ \\
\hline Inflammation: & $1 \cdot 9$ & $1 \cdot 57$ & $1 \cdot 73$ & $1 \cdot 4$ & $1 \cdot 62$ \\
Atrophy: & $0 \cdot 85$ & $0 \cdot 96$ & $0 \cdot 86$ & $1 \cdot 16$ & $1 \cdot 37$ \\
Activity: & $2 \cdot 33$ & $0 \cdot 54^{\star}$ & $1 \cdot 46 \star \star$ & $0 \cdot 222^{\star \star}$ & $2 \cdot 12$ \\
H pylori infection: & $2 \cdot 48$ & 0 & 2 & 0 & $1 \cdot 87$ \\
Intestinal metaplasia: & $0 \cdot 2$ & $0 \cdot 15$ & $0 \cdot 26$ & $0 \cdot 33$ & $0 \cdot 12$ \\
Total score & $7 \cdot 76$ & $3 \cdot 22$ & 6.31 & $3 \cdot 11$ & $7 \cdot 1$ \\
\hline
\end{tabular}

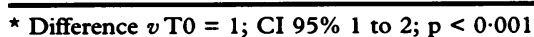

$\star \star$ Difference $v$ T0 $=0.87$; CI $95 \% 0.08$ to $1 ; \mathrm{p}<0.05$

$\star \star$
$\star \star \star$
Difference $v \mathrm{~T} 0=0.87 ; \mathrm{CI} 95 \% 0.08$ to $1 ; \mathrm{p}<0.05$. 
T0, 0.5 at T1; CI 1.23 to $2.05 ; \mathrm{p}<0.001$ ). Inflammation did not seem to reduce significantly even though lympoid follicules were found in seven cases (three $H$ pylori negative and four $H$ pylori positive)

SIX MONTH RESULTS (T2)

Only 26 patients returned for six month follow up. The other 22 refused endoscopy, mostly because they were asymptomatic.

Eighteen patients were $H$ pylori negative; in three cases reinfection had occurred. Two patients, who were $H$ pylori positive at T1, were now negative without any further treatment. The score for gastritis was further reduced in $H$ pylori negative patients (mean value 3.0 at T2; p < 0.001; CI 3.45 to 6.11 ), while in nonresponders it relapsed to $7 \cdot 1$. Gastritis activity was significantly reduced by $H$ pylor $i$ eradication (mean difference $v$ T0 $=2$; CI 1.49 to $2.51 ; p<0.001)$. In fact, reduction in polymorph infiltration, evident soon after treatment, continued until virtual disappearance during follow up when eradication was stable $(0.22$ at T2). In $H$ pylori positive patients there was a rapid reactivation of gastritis (from 1.5 to $2 \cdot 1)$. In $H$ pylori negative patients there was a trend towards a reduction in inflammation ( 1.9 at T0, 1.57 at $\mathrm{T} 1$ and 1.4 at T2) with only one case of follicular gastritis, even though this was not significant at six month follow up.

\section{Discussion}

The therapeutic approach to $H$ pylori gastric infection is not yet standardised. Single treatment with antibiotics or bismuth salts for four to eight weeks gives poor results. ${ }^{14}{ }^{15}$ Better outcomes were obtained with combined treatments using these drugs, obtaining more than $90 \%$ eradication in some cases. ${ }^{16}$ The main drawback of these treatments is the high rate of side effects, which impairs the compliance of patients.

In our study we have shown that triple treatment for 10 days can eradicate $H$ pylori gastric mucosa in $69 \%$ of cases, with excellent compliance among patients.

Histological assessment showed a close association between antral lesions and $H$ pylori infection, which agrees with the findings of other authors. ${ }^{11} 1718$ In fact, normal gastric mucosa with $H$ pylori positivity has rarely been reported. ${ }^{1920}$ In our series all the patients showed altered histology before treatment.

The inflammatory process is characterised by lymphocyte and polymorph infiltration of the superficial lamina propria in the earliest stage of gastritis, while in severe cases the infiltrate extends towards the mucosal surface, $^{25}$ sometimes forming lymphoid follicules. ${ }^{12}$ It has been recently suggested that such lymphocytic reaction to $H$ pylori could be a pathogenic factor for primary $B$ cell gastric lymphoma. $^{13}$

In our patients the grade of polymorph infiltration (activity) strongly correlated with the density of $H$ pylori colonisation. The absence of polymorphs was always associated with eradication of the bacteria. Furthermore, in the three cases of reinfection we observed a rapid reactivation of gastritis.

The Sydney system ${ }^{10}$ distinguishes activity, which is an expression of how the ongoing situation is directly influenced by the presence or absence of bacteria, from inflammation and atrophy. Our results suggest that inflammation can be reduced (approaching statistical significance) after a long follow up period, but that atrophy is irreversible. When the damage is advanced, inflammation evolves in atrophy even if $H$ pylori has been eradicated.

In conclusion, short term triple treatment is effective in eradicating $H$ pylori from gastric mucosa, immediately decreasing gastritis activity until it has virtually disappeared after six months. Inflammation shows a tendency to resolve, particularly in cases in which histological damage is not advanced. In cases of chronic inflammation atrophic damage is irreversible, and can become more evident with the disappearance of infiltrate.

1 Morris BJ, Nicholson G. Ingestion of Campylobacter pyloridis causes gastritis and raised fasting gastric pH. $A m$ pyloridis causes gastritis and raise

2 Rauws EAJ,Langenberg W, Houthoff HJ, Zanen HC, Tytgat GNJ. Campylobacter pyloridis-associated chronic antral gastritis. Gastroenterology 1988;94:33-40.

3 NcNulty CAM. Campylobacter pyloridis-associated gastritis. F Infect 1986;13:107-13.

4 Hazell SL, Lee A. The adaptation of motile strains of Campylobacter pyloridis to gastic mucus and their association with gastric epithelial intercellular spaces. In Pearson AD, Skirrow MB, Lior H, Rowe B, eds. Campylobacter III. London: Public Health Laboratory Service, 1985:189-91.

5 Hazell SL, Lee A, Brady L, Hennessy W. Campylobacter pyloridis and gastritis: association with intercellular spaces and adaptation to an environment of mucus as spaces and adaptation to an environment of mucus as
important factors in colonisation of the gastric epitheimportant factors in colonisation of
lium. $\widetilde{f}$ Infect Dis 1986;153:658-62.

6 Caselli M, Figura N, Trevisani L. Pattern of physical modes of contact between Campylobacter pylori and gastric epithelium: implication about bacterial pathogenicity. $A m$ f Gastroenterol 1989;84:511-13.

7 Figura N, Bugnoli M, Cusi MG. Pathogenic mechanisms of Helicobacter pylori: production of cytotoxin. In: Malfertheiner P, Ditshuneid H, eds. Helicobacter pylori, gastrit and peptic ulcer. Berlin: Springer-Verlag, 1990:86-95.

8 Rauws EAJ. Therapeutic attempts at eradication of Campylobacter pylori. Eur f Gastroenterol Hepatol 1989;1 34-41.

9 Lamouliatte H. Traitment des gastrites chroniques associées à Campylobacter pylori. Gastroenterol Clin Biol 1989 à Campylo.

10 Misiewicz JJ, Tytgat GNJ, Goodwin CS, et al. The Sydney system: A new classification of gastritis. Working Part Reports. Sydney: World Congress of Gastroenterology 1990:1-10.

11 Correa P. Chronic gastritis: A clinico-pathological classifica tion. Am $\mathcal{F}$ Gastroenterol 1988;83:504-9.

12 Stolte M, Eidt S. Lymphoid follicles in antral mucosa immune response to Campylobacter pylori? $\mathcal{f}$ Clin Patho 1989;42:1269-71.

13 Wotherspoon AC, Ortiz-Hidalgo C, Falzon Mr, Isaacsor PG. Helicobacter pylori-associated gastritis and primar! PG. Helicobacter pylori-associated gastritis and prim

14 Marshall BJ, Hislop J, Glancy R, Armstrong J. Histologica improvement of active chronic gastritis in patients treate improvement of active chronic gastritis in patients treatec
with De-Nol. Aust NZ $\mathfrak{Y}$ Med 1984;14(Suppl 4):907.

15 Glupczynski Y, Burette A, Labbe M, Deprez C, De Reucl M, Deltenre M. Campylobacter pylori associated gas tritis: a double blind placebo-controlled trial with amox icillin. Am $\mathcal{f}$ Gastroenterol:365-72.

16 Borsch G, Mai U, Opferkuch W. Oral triple therapy ma effectively eradicate Campylobacter pylori in man: a pilo study. Gastroenterology 1988;94:44.

17 Dooley CP, Cohen H, Fitzgibbons P, et al. Prevalence o Helicobacter pylori infection and histologic gastritis in asymptomatic persons. $N$ Engl f Med 1989;321:1562-6.

18 Goodwin CS, Armstrong JA, Marshall BJ. Campylobacte pyloridis, gastritis, and peptic ulcer. $\mathcal{F}$ Clin Pathol 1986 pyloridis, gast

19 Marshall BJ, Warren JR, Francis GJ, et al. Rapid urease tes in the management of Campylobacter pyloridis-asso ciated gastritis. Am $\mathcal{F}$ Gastroenterol 1987;82:200-6.

20 Raskov H, Lang C, Gaarslev K, Fisher-Hansen B, Haucl O. Screening for Campylobacter pyloridis in patients witl upper dyspepsia and the relation to inflammation upper dyspepsia and the relation to inflammation 0
human gastric antrum. Scand $\mathcal{F}$ Gastroenterol 1987;22 568-71. 